\title{
EDITORIAL: Pacific media advocacy
}

N SAMOA during July 2015, a new era in Pacific journalism education and training advocacy was born with the establishment of Media Educators Pacific (MEP) after a talkfest had gone on for years about the need for such a body. A draft constitution had even been floated at a journalism education conference hosted at the University of the South Pacific in 2012. The initiative created unity of sorts between the Technical, Vocational and Educational Training (TVET) media institutes from Fiji, Samoa, Solomon Islands and Vanuatu, and the regional University of the South Pacific journalism programme. Founding president Misa Vicky Lepou of the National University of Samoa pledged at the time to produce a vision with a difference:

In a region where media is the least respected profession, governments look to revenue-earning industries and community interests to take care of how media education courses are run. Pacific educators also tend to focus on what is happening on a global scale, forgetting what needs to be done on a local front. (Pacific media educators join forces, 2015)

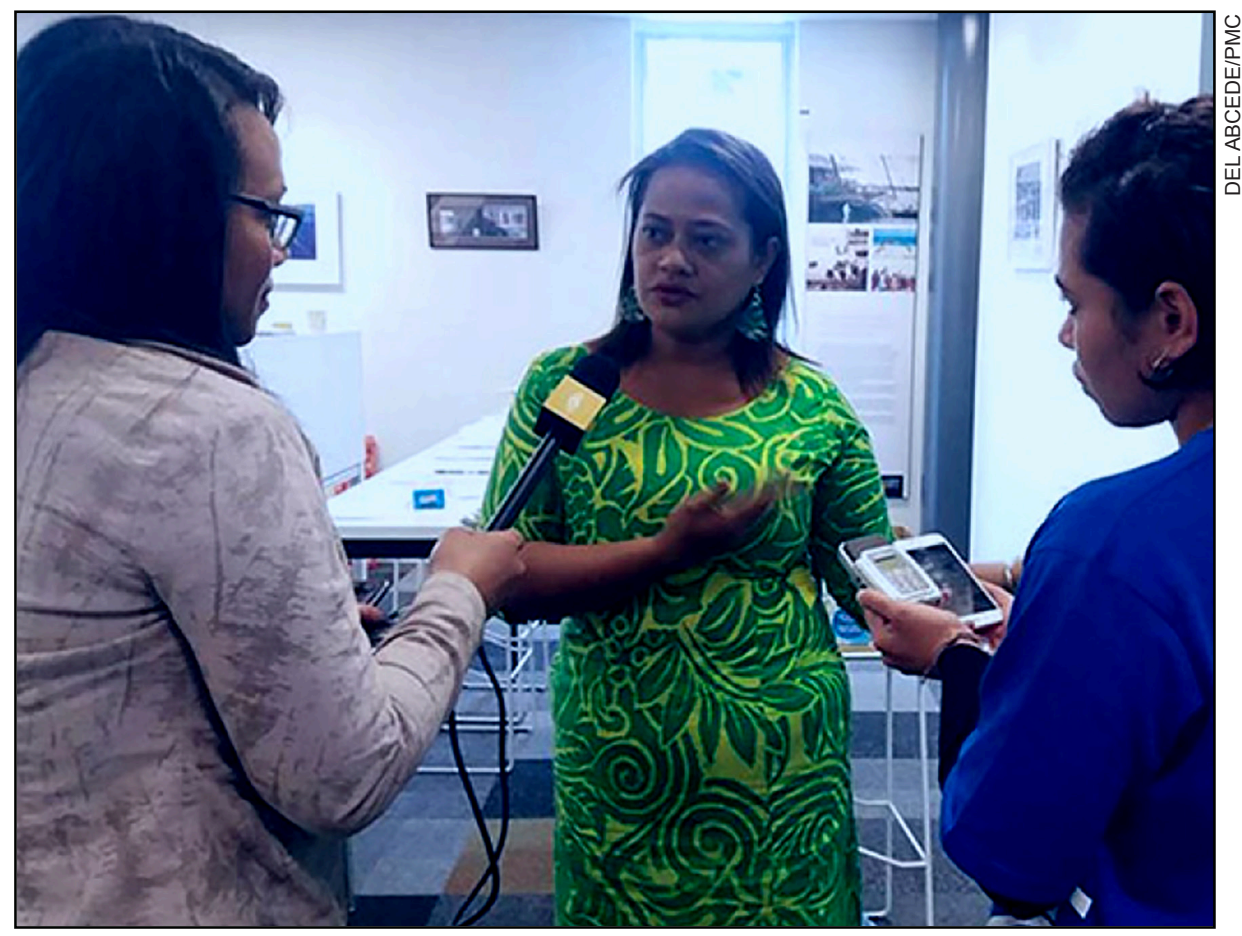

Figure 1: MEP's president Misa Vicky Lepou being interviewed by Pacific journalists in Auckland. 
Fast forward a year to July 2016 and a group of seven MEP advocates and colleagues, including Misa and Dr Shailendra Singh from USP, were sponsored by the newly created NZ Institute for Pacific Research (NZIPR and UNESCO) to attend the JERAA-Pacific Media Centre Preconference and the Fourth World Journalism Education Congress (WJEC) at Auckland University of Technology in New Zealand. They were also supported by a group of media educators from Asia with the assistance of the Asia NZ Foundation (MEP pushes ahead, 2016)

From an Asia-Pacific perspective, one of the highlights of the combined conferences was a seminar on corruption sponsored by Transparency International New Zealand. Convenor Fuimaono Tuiasau noted that corruption was one of the biggest challenges facing the region, along with climate change and the depletion of fisheries resources. 'Corruption is much like cancer: It's got to be treated early, otherwise there are going to be massively expensive interventions - as we see in Africa, as we see in Asia, and as we see in South America,' Tuiasau lamented.

One of the panelists, celebrated Taimi 'o Tonga publisher Kalafi Moala, remarked about Tonga after the kingdom had elected a pro-democracy majority in Parliament in 2014, 'We thought all we needed to do was change the system' (Corruption in the Pacific, 2016). However, change was easier said than done. The democrats thought that all they needed to do was have their leaders and government held accountable. Instead, things turned pear-shaped within two years and now the government of 'Akilisi Pohiva has been sacked by an unprecedented royal intervention and Tongans are due to go to the polls to elect a new government in mid-November 2017 in what may be a further setback for media freedoms.

Both Shailendra Singh and Alexander Rheeney outlined similar experiences in Fiji and Papua New Guinea respectively. 'Corruption is blamed for Fiji's debilitating "coup culture" - we've had four coups in the last 25 years,' observed Singh. Rheeney, formerly chief editor of the PNG Post-Courier and now president of the Media Council of PNG, is seriously concerned about the absence of adequate checks and balances in Papua New Guinea and the lack of media transparency around government accountability to the public. He said there had been a 'classic example' in 2015 when the government 'basically bulldozed the national budget through without allowing Parliament to dissect and to debate the money plan' for the year.

This debate set the scene for further discussion by a panel two days later at WJEC when a group of MEP educators discussed journalism education in the Pacific. They also touched on issues of corruption and how media schools were teaching strategies to deal with them. As convenor of the panel I spoke of how the highly politicised educational environment in some countries impacted on journalism education, and how media schools had been forced to wean themselves off a legacy of short courses (with donor agendas being too influential) rather 
than serious journalism education with recognised qualifications as established in many countries.

I also spoke about how political risks and real dangers of threats and physical attacks confronted student journalists all the time. As an example, I offered the incident on 8 June 2016 when Papua New Guinea police in camouflage fatigues opened fire on a peaceful student protest, wounding at least 23 people. That followed an earlier tragedy in 2001 when PNG shot dead three protesting students. After showing a brief video made by students at the University of Papua New Guinea. about the 2016 shootings, another panelist, Emily Matasororo (of UPNG), spoke of the deep dilemmas faced by student journalists covering the crisis.

This tragedy was written about in an earlier edition of $P J R$ that was themed around the JERAA-PMC-WJEC joint conferences (Matasororo, 2016). A first batch of papers was published from the joint conferences, and now in this edition we are wrapping up the balance of the articles.

W HILE the United States was enduring its Vietnam war upheaval and the challenge to the presidency of the Watergate break-in, Samoa was enjoying a period of the finest truth-to-power global reportage, Misa Vicky Lepou brings this proud period alive. Tracing some of the highlights of Savea Sano Malifa's trailblazing investigations and struggle for press freedom with the Samoa Observer, Misa laments an erosion of ethics and media professionalism in contemporary times.

In the Philippines, Jeremaiah M. Opiniano deploys a phenomenological study to analyse the roles and purposes of graduate journalism education based on research involving 16 Asian students from three graduate journalism schools.

The two daily newspapers of Solomon Islands, the Solomon Star and Island Sun, are the subject of an inquiry into the use of anonymous sources by senior Star journalist Eddie T. Osifelo. Finding widespread and questionable use of anonymous sources in the dailies, Osifelo notes that the two newspapers face many challenges ranging from politicians and other public figures to 'threats, intimidation [and] compensation demands to court battles'.

Dave Mandavah in Port Vila offers a commentary about the status and state of the two-year diploma course in journalism and media and the Vanuatu Institute of Technology (VIT). He backgrounds this AusAID TVET initiative and the development of this programme in the face of difficult odds.

Julie Cleaver provides a transcript of a vibrant panel debate about the level of corruption in the Pacific and the challenges facing journalists, journalism educators and the media. Sponsored by Transparency International New Zealand, convenor Fuimaono Tuiasau facilitated a lively discussion featuring Kalafi Moala, Shailendra Singh, and Alexander Rheeney, with a summing up by PMC chair associate professor Camille Nakhid. 
Rounding off the themed papers for this edition, Mackenzie Smith offers another transcript, this time on journalism training and education-the new advocacy era. This seminar focused on a range of issues including academic freedom, freedom of expression and even journalism safety issues, such as the shooting by police of peacefully protesting students on the edge of the University of Papua New Guinea campus on 8 June 2016. The repercussions from this shocking event are still unraveling. Chaired by PMC's Professor David Robie, the panel also included Emily Matasororo, Shailendra Singh, Misa Vicky Lepou, and Dave Mandavah with Eliki Drugunalevu (USP) responding.

Al Jazeera has been the defining feature in developing news media in the Middle East (and beyond). The satellite broadcasting network has played a key role in bringing stories and perspectives that other international media ignore, especially on many human rights issues. And it played an important role during the ill-fated Arab Spring upheaval in five nations. Tarek Cherkaoui, an AUT doctoral graduate from Qatar specialising in the communication crises of the region and the author of The News Media At War, has devoted the Special Report in this PJR edition to the so-called Gulf crisis. He analyses the allegations by the 'gang of four'- Saudi Arabia, United Arab Emirates, Bahrain and Egypt - that the tiny emirate supports terrorism.

No Frontline (journalism-as-research) article has been published in this edition, but the series will return with the next edition.

In the unthemed section, UNSW Forced Migrant Research Network activist and researcher Victoria Jack offers a case study of camps on the Thai-Burma border to highlight the 'exclusion' of refugees from the common world and the failure of news media to give 'voice' to their communities.

Catherine Strong and Fran Tyler analyse how, unlike in many Western countries, political lobbyists in New Zealand are 'able to skirt around scrutiny' in the media because journalists neglect to identify lobby organisations to the public.

David Robie dissects half a century of Indonesian rule in the Melanesian region of West Papua and challenges why New Zealand and other media are reluctant to shed their 'blind spot' about their near neighbour. Globally, the issues of Papuan self-determination and human rights violations are increasingly becoming a focus of storytelling.

In an article about the challenges confronting Muslim Indonesian mothers teaching their daughters piety, modesty and tolerance, Hanny Savitri Hartono exposes the issue of roadside billboards displaying harmful products such as cigarettes and sexualised images of women. Tragically Hartono died suddenly in early 2017 while completing her Massey University doctorate which was awarded posthumously. Her supervisors, Sharyn Davies and Graeme MacRae, assisted with the completion of this journal article from the doctoral research.

Completing the journal edition is Philip Cass who deconstruct Commando 
comics, which have provided a consistent image of Australian and New Zealand ancestors at war-'men, who are inevitably tall, bronzed, shirtless, contemptuous of authority' and with prodigious warrior ability.

This edition of Pacific Journalism Review will be launched during festivities marking the 10th anniversary of the founding of the Pacific Media Centre, and also the launching of a new Tuwhera Open Access platform for the companion publication Pacific Journalism Monographs.

\section{Professor David Robie \\ Editor \\ Pacific Journalism Review \\ pjreview.aut.ac.nz}

\section{References}

Cherkaoui, T. (2017). The news media at war: The clash of western and Arab networks in the Middle East. New York, NY: L. B. Tauris.

Corruption in the Pacific - a threat to cultural identity (2017). Pacific Journalism Review : Te Koakoa, 23(2), 70-92 doi: 10.24135/pjr.v23i2.331

Matasororo, E. (2016). Standoff in Papua New Guinea: Students take issue over corruption. Pacific Journalism Review : Te Koakoa, 22(2), 13-19. doi: 10.24135/pjr.v22i2.71

MEP pushes ahead with plan for Pacific media educators and trainers (2016, July 20). Asia Pacific Report. Retrieved from https://asiapacificreport.nz/2016/07/20/meppushes-ahead-with-plan-for-pacific-media-educators-and-trainers/

Pacific media educators join forces (2015, July 1). The National University of Samoa website. Retrieved from www.nus.edu.ws/s/index.php/87-nus/news-events/297media-educators-pacific-mep-join-forces 